\title{
New and recently described Gomphonema species (Bacillariophyceae) from Siberia
}

\author{
ERWIN REICHARDT \\ Bubenheim 136, 91757 Treuchtlingen, Germany
}

\begin{abstract}
This paper reports on five species of the genus Gomphonema, which seem to be widespread at least in Siberia or in other regions, too. Due to their wide distribution their knowledge is of special importance. Three species are described as new (G. demersum, G. jergackianum and G. marvanii) based on light-(LM) and scanning electron microscopical (SEM) investigations. Important characters delimiting these species from similar taxa are discussed. For two recently described species (G. liyanlingae Metzeltin et LANGE-Bertalot and G. khentiiense Metzeltin, Lange-Bertalot et Nergui) ultramicroscopical details or SEM micrographs are presented for the first time and additional data on their distribution are given.
\end{abstract}

Key words: Bacillariophyceae, diatom morphology, Gomphonema, new species, Siberia, taxonomy, ultrastructure

\section{Introduction}

Compared to the large area of Siberia the number of papers on diatoms of this region is extremely small. Moreover many of these papers are not up to date or are obtainable only with difficulties (see e.g. Foged 1993 for references). Systematic investigations concentrate on Lake Baikal (e.g. POPOVSKAYA et al. 2002), many studies on other locations seem to be based on accidental random samples. This is also the case with the materials investigated in the present paper.

In August 2008 Miss Veronika Eckart collected some samples from streams and lakes in the Jergacki region, which is situated in the western Sajan mountains south of Abakan and from the river Jenisej near Jenisejsk, north of Krasnojarsk and also north of the conjunction of the river Angara. At first glance the investigation of these samples showed mainly diatoms, which also can be found in Europe under similar conditions. In addition, some diatoms typical for Siberian waters could be observed (e.g. taxa of the Gomphonema quadripunctatum (ØSTRUP) WISLOUCH - complex or Cymbella stuxbergii CLEVE in CLeve \& GruNOw. However, a thorough examination proved the presence of many interesting diatoms, among them some poorly known or undescribed species of Gomphonema could be found. A search for similar diatoms in slides from other localities in Siberia and in the literature showed that these Gomphonemata occur elsewhere in Siberia or other regions, too. Because of this fact their description seems to be justified and of importance.

\section{Material and methods}

This study is based on detailed LM and SEM investigations of the following materials.

S1161 coll. Reichardt. Right bank of the River Angara in the city of Irkutsk, Siberia, Russia (14. 9.1987). Material ex coll. Lange-Bertalot.

S2779 coll. Reichardt. Stream in the Jergacki region, Western Sajan Mountains, Siberia, Russia. Leg.: V. Eckart, 8/2008.

S2780 coll. Reichardt. Stream in the Jergacki region, Western Sajan Mountains, Siberia, Russia. Mosses with mud. Leg.: V. Eckart, 8/2008.

S2783 coll. Reichardt. Jenisej near Jenisejsk (Enisejsk), Siberia, Russia. Aquatic mosses. Leg.: V. Eckart, $8 / 2008$

The following samples were examined to study additional valves of $G$. jergackianum spec. nov.

S1384 coll. Reichardt. Julma Ölkky near Kuusamo, Finnland. Leg. A. \& R. Dorn (13.6.1992). Material ex coll. Lange-Bertalot. See Lange-Bert. \& Metzeltin (1996) for further data.

S1869 coll. Reichardt. Wolfsee, a little lake in 
„Hienheim Forest“", Bavaria, Germany. Epiphytic algae. $\mathrm{p}_{\mathrm{H}}$ about 6. Leg. E. Reichardt (2.5.1997).

The samples were prepared according to standard techniques by boiling in sulfuric acid and oxidation with nitric acid. Naphrax and Hyrax were used as mountants of the LM-slides. Light micrographs were taken with a digital camera Imagingsource DMK41AF02. For SEM studies the material was sputter coated with about 20 $\mathrm{nm}$ of gold and investigated in a modified Leitz AMR 1200B scanning electron microscop at an accelerating voltage of $15 \mathrm{KV}$.

In addition single slides from two sites of Lake Baikal, River Angara near Irkutsk and the reservoir near Bratsk were investigated. These slides in coll. Reichardt were prepared by Ditmar Metzeltin (leg. 1987).

\section{Results and Discussion}

Gomphonema demersum E. REICHARDT, sp. nov. (Figs 1-37)

Frustula aspectucincturaemodice cuneiformia seriebus punctorum in copulis distincte aspectabilibus.

Valvae minime clavatae, lanceolatae, margines ad apices versus paulatim attenuatae. Vertices subobtuse rotundati poli basales angustius rotundati. Longitudo 13-41 $\mu \mathrm{m}$, latitudo 3.6-6 $\mu \mathrm{m}$. Raphe lateralis fissuris paulo arcuatis quoad individua maiora vel fere filiformis fissuris minime arcuatis quoad individua minora. Extrema centralia externa internaque raphis aspectabilia extrema interna declinata distantius inter se quam extrema externa recta. Dissimilitudo extremorum centralium vix aspectabilis quoad individua minora. Area axialis modice lata lanceolata dilatata ad aream centralem versus. Area centralis late rhombico-lanceolata continuum cum area axiali formans. Stigma solitare unilateraliter in nodulo centrali positum. Striae transapicales parum vel modice radiantes, per occasionem etiam subparallelae, 12-16 (plerumque circiter 14) in $10 \mu \mathrm{m}$. Puncta striarum non aspectabilia in microscopio photonico.

Holotypus: S2783-T01 Coll. Reichardt in Museo Botanico Berolinense (B).

Isotypus: ZU6/85 in collectione Bremerhaven (BRM). Locus typicus: River Jenisej in Jenisejsk, Siberia. (leg. V. Eckart, August 2008).

Cells moderately cuneate in girdle view with a row of small but clearly visible pores on the girdle bands.

Valves lanceolate, only very slightly gomphonemoid-cuneate. Head pole obtusely rounded, basal pole narrower. Length 13-41 $\mu \mathrm{m}$, breadth 3.6-6 $\mu \mathrm{m}$. Raphe lateral with somewhat inflected external raphe fissures in large valves, almost filiform and straight in small individuals. External and internal central raphe endings distinguishable (with difficulty in small valves) the latter are wider apart and deflected to the same side. Axial area lanceolate, widening into a broad rhombic-lanceolate central area which is not clearly separated. A single isolated stigma on the primary side of the central nodule. Striae slightly or moderately radiate, occasionally also nearly parallel, 12-16 (mostly about 14) in $10 \mu \mathrm{m}$. Stria pores not distinguishable.

In SEM the external central raphe fissures are slightly expanded to form elongate, weakly drop-shaped central raphe endings (Fig. 32). Inner central raphe fissures unilaterally bent approximately at a right angle ending in recurved depressions (Fig. 35). The circular external stigma opens internally in an elongated pore. Alveoli with straight margins, stubs or struts are lacking (Figs $35,36)$. Externally the foramina are kidney-, C-, $3-$, or S-shaped and situated in slight depressions visible only at oblique viewing (Figs 32-34). A separated pore field is present at the foot pole. The rows of small poroids visible in girdle view are in the girdle-bands (Figs. 31, 37). Below the striae the mantles of the valves are without additional structures.

A similar species, though not closely related is $G$. venusta PASsY, KocIOLEK et Lowe (correct ending is -um). It differs mainly by biseriate areolae and other ultrastructural details like e.g. the shape of the foramina or the internal central raphe endings. $G$. venustum has marginal laminae and the mantle bears a row of small round poroids. Both of these structures are lacking in $G$. demersum. In

Figs 1-31. Gomphonema demersum, LM (except Fig. 14): (1-14, 31) Type material, (6) Holotypus, (14) SEM. Valve exterior (14a) Centre of Fig. 14 enlarged $(\times 4)$; (15-18) Lake Baikal; (19-29) Angara in Irkutsk (S1161); (30) Angara near Irkutsk (leg. 1987); (31) Girdle view. Scale bar $10 \mu \mathrm{m}$.

Figs 32-37. Gomphonema demersum. SEM (type material except Fig. 37): (32) Centre of valve exterior; (33) Upper half of valve exterior with head pole; (34) Exterior of foot pole with pore field; (35) Details of interior valve centre with alveoli, stigma opening and deflected central fissures; (36) Oblique view to centre of valve showing exterior and interior of the mantles. No additional pores in the mantles; (37) Frustule in girdle view showing a row of poroids in the girdle band (S1161). Scale bars $2 \mu \mathrm{m}$. 

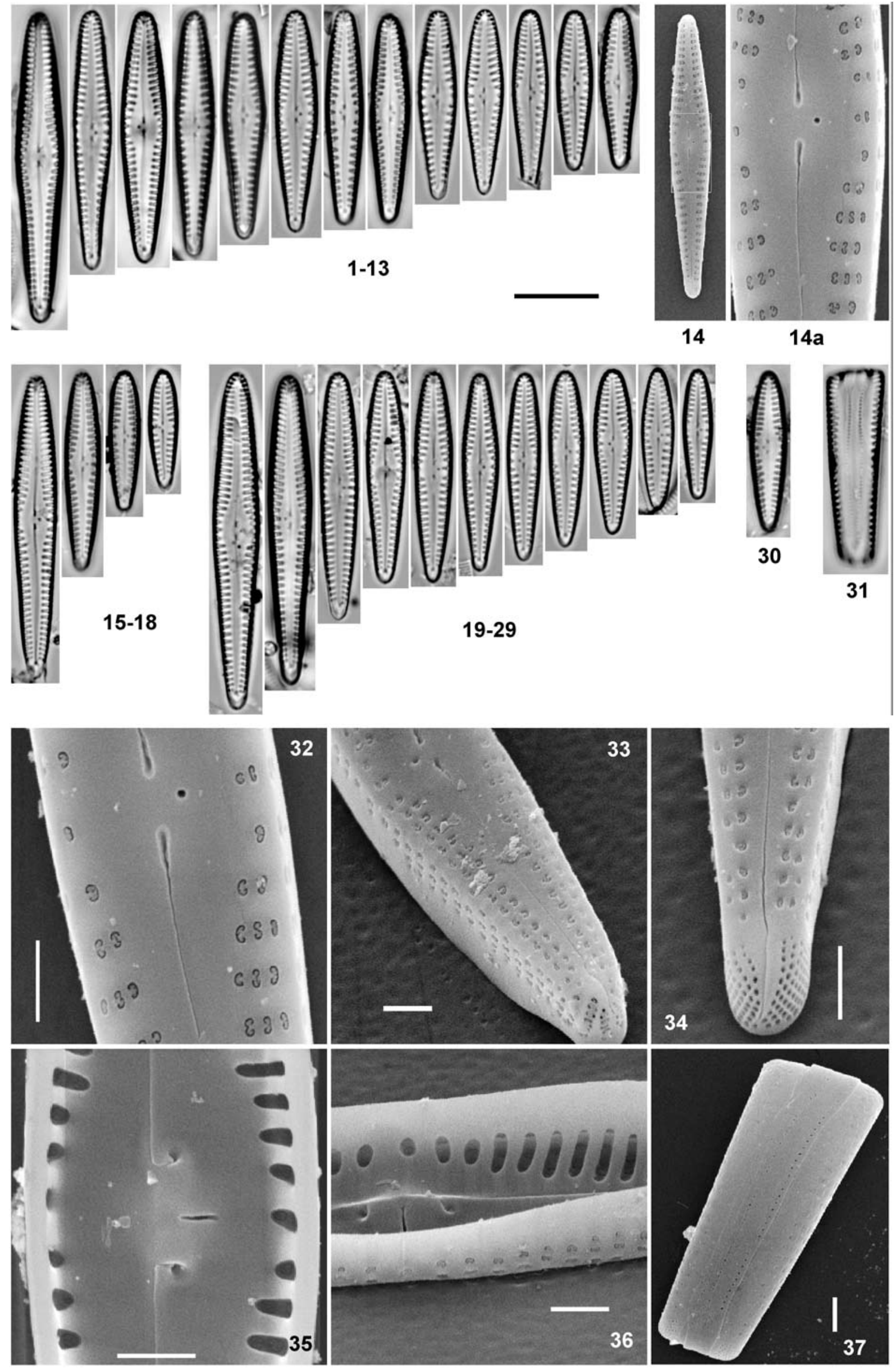
addition, G. venustum is bigger and more coarsely striated. Other similar Gomphonemata can be found in SchmidT et al. (1874-1959) pl. 248/(4) $5-9$. They all differ from $G$. demersum in their shape, the areae and the density of the striae. $G$. tenerrimum M. SCHMIDT et FrICKE (1.c. pl. 248/7), which looks most similar to $G$. demersum differs in size, wider areae and the broadly rounded head pole. A notable detail in $G$. demersum is the stria running to the stigma. It is often a little bit longer than the stria on the opposite side.

G. demersum seems to be widespread in Siberia. During this investigation, detailed studies (LM and SEM) were carried out in material S1161 (Angara in Irkutsk) and S2783 (Jennissej River), but it was also observed in slides from Lake Baikal, the reservoir near Bratsk and Angara river near Irkutsk. This diatom is also depicted in Metzeltin, Lange-Bert. \& Nergui, (2009) pl. 173/9 and pl. 174/29-30 (nec 31). Apparently G. demersum belongs to a complex of taxa with smilar structures, which is common or widespread in Siberia. This opinion is confirmed by figures in Metzeltin, Lange-Bert. \& Nergui, (2009, pl. 173/10, 23-31) and personal observations.

\section{Gomphonema jergackianum E. ReICHARDT, sp. nov. (Figs 38-57)}

Frustula aspectu cincturae modice cuneata seriebus 1-2 punctorum in prolongatione striarum in limbum.

Valvae lanceolate-clavaeformes marginibus saepe unilateraliter convexioribus itaque valvae minime cymbelloideae apparentes verticibus obtuse et late rotundatis polis basalibus angustius rotundatis.

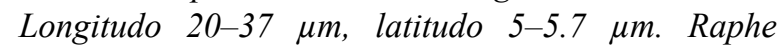
paulo lateralis fissuris aliquid undulatis. Extrema centralia raphis interne externeque paene aequilonga declinatione inconspicua. Area axialis lanceolata dilatata ad aream centralem versus hic ad mediam lateris dilatata. Stigma solitarium prope nodulum centralem positum a stria media satis separatum. Striae transapicales modice radiantes circiter 12 in $10 \mu \mathrm{m}$, $s u b$ vertices paulo densiores et subparallelae. Puncta striarum vixdum aspectabilia microscopio photonico.

Holotypus: S2780-T01 Coll. Reichardt in Museo Botanico Berolinense (B).

Isotypus: ZU6/84 in collectione Bremerhaven (BRM).

Locus typicus: Stream in the Jergacki-region, Western Sajan Mountains, Siberia. (leg. V. Eckart, August 2008).

Cells slightly cuneate in girdle view with series of
1-2 punctae on the mantle.

Valves clavate, lanceolate, margins on one side often somewhat more convex than at the opposite side, valves therefore slightly cymbelloid. Head pole obtuse and more broadly rounded than the basal pole. Length $20-37 \mu \mathrm{m}$, breadth 5-5.7 $\mu \mathrm{m}$. Raphe lateral and slightly undulate. External and internal central raphe endings inconspicuous and hardly distinguishable in LM. Axial area lanceolate, widening into a roundish central area occupying about half the wide of the valve. A single isolated stigma on the primary side of the central nodule. Striae about 12 in $10 \mu \mathrm{m}$, moderately radiate, sometimes becoming almost parallel at the headpole. Stria pores indistinct or indistinguishable.

In SEM the external central raphe fissures are hardly expanded. Striae uniseriate with $\mathrm{C}-$ or sometimes weakly 3-shaped foramina. External stigma opening round, a circular bulge around the pore like in G. pumilum is lacking (Fig. 54). Internally the stigma opening appears small and only very little widened transversely, not slit-like. Inner central raphe fissures deflected to one side mostly with an undulation which is characteristic in the G. pumilum-group (cf. REICHARDT 1997) and lacking in G. clavatulum (cf. REICHARDT 1999). Alveoli without stubs or struts (Figs. 55, 56). Both poles, especially the foot pole, show pseudoseptum-like thickenings of the cell wall (Fig. 57).

In LM this species appears like an intermediate form between G. clavatulum E. REICHARDT and G. pumilum (Grun.) E. Reichadt et LANGE-Bert. It differs from $G$. clavatulum mainly by the more lanceolate outline, i.e. the upper part of the valve is narrower, and the wider axial area. In addition, the raphe is less undulate than in $G$. clavatulum and there are only 1-2 rows of punta in the mantles contrary to G. clavatulum or the whole G. clavatum (sensu auct.) - complex where in general 2-3 rows of poroids are present. The broadly rounded head pole and the poroids in the mantles distinguish G. jergackianum clearly from G. pumilum.

G. jergackianum is not rare in the type-material and in sample S2779. It is not restricted to Siberia but also lives in the northern hemisphere in electrolyte-poor oligotrophic waters. LANGEBertalot \& Metzeltin (1996: 74, pl. 63/15-17) 

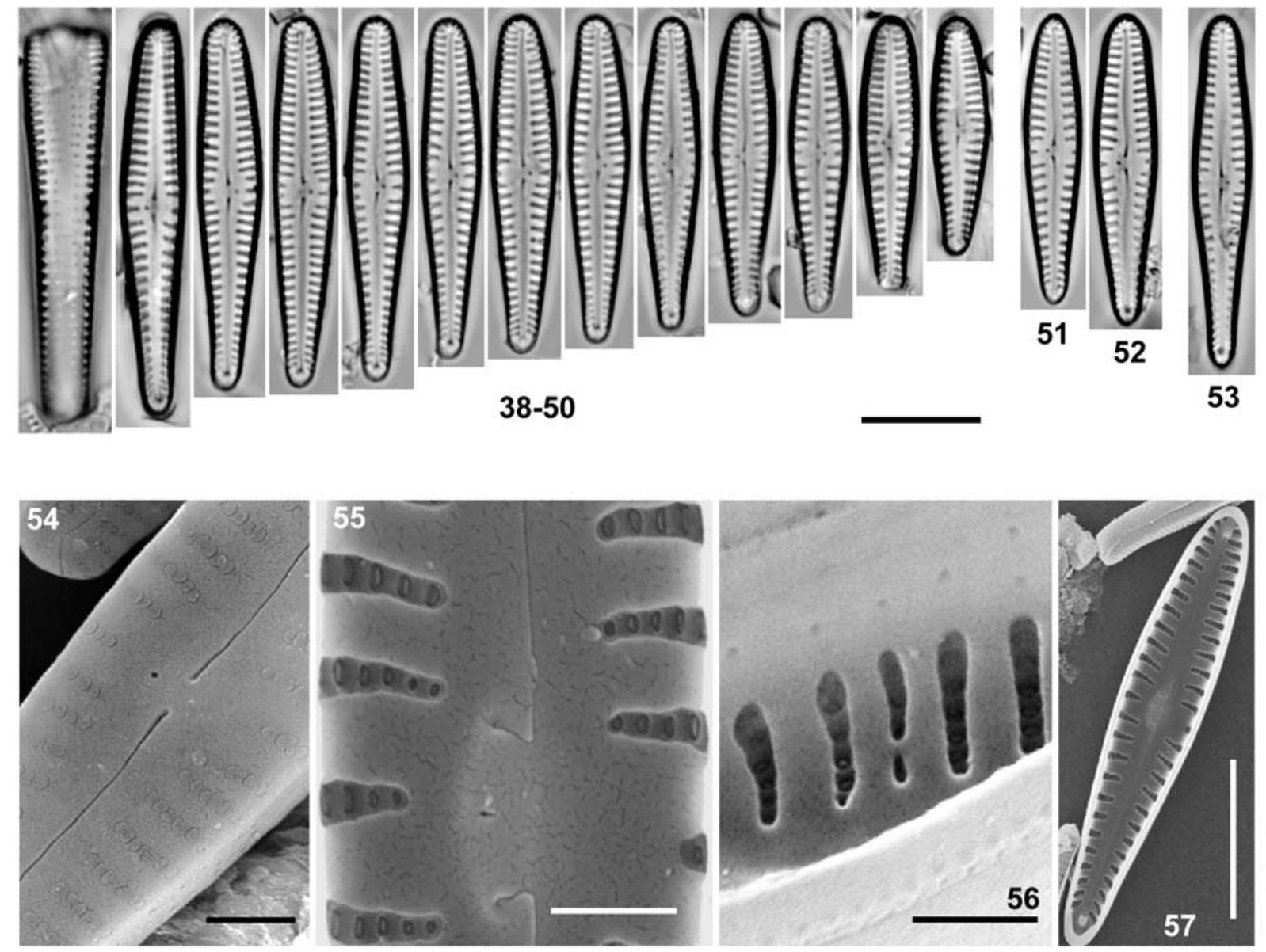

Figs 38-57. Gomphonema jergackianum, Figs 38-53 LM: (38, 40-49) Type material, (38) Girdle view, (43) Holotype, (39, 50) Jergacki (S2779); (51-52) Wolfsee, Bavaria (S1869); (53) Julma Ölkky, Finnland (S1384); (54-57) SEM (S1869), (54) Exterior of valve centre, (55) Centre of valve interior, (56) Inside view showing poroids in the valve mantle, (57) Interior view of whole valve showing pseudoseptum-like structures at the poles. Scale bars $10 \mu \mathrm{m}$ (LM and Fig. 57), $2 \mu \mathrm{m}$ (Figs 54-56).

show this species as „Gomphonema spec. Nr. 1“ (,G. spec. Nr. 3“ in plate 63) from Julma Ölkky in Finland and report on occurrences in Skandinavia, Iceland and Germany. The findings in the slightly acid lake Wolfsee in Bavaria confirm these statements.

\section{Gomphonema marvanii E. REICHARDT, sp. nov. (Figs 58-87)}

Valvae leniter gomphonemoideae-clavatae marginibus fere rectis verticibus obtuse cuneatim rotundatis saepe minime protractis, polis basalibus angustius

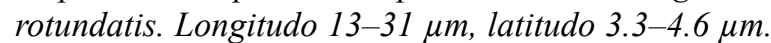
Raphe filiformis et fere recta. Extrema centralia externa internaque in microscopio photonico non dissimilia. Area axialis anguste linearis, area centralis transverse dilatata una vel duae striae utrimque abbreviatae. In area centrali 4 stigmata adsunt. Striae transapicales modice vel distincte radiatae, 13-18 (plerumque 1518) in $10 \mu \mathrm{m}$, sub apices interdum paene parallelae et densius sitae inter se circiter 20 in $10 \mu \mathrm{m}$. Puncta striarum non aspectabilia in microscopio photonico, areolae omnino biseriatae sunt.

Holotypus: S1161-T01 Coll. Reichardt in Museo Botanico Berolinense (B).

Isotypus: ZU6/83 in collectione Bremerhaven (BRM). Locus typicus: Right bank of river Angara in Irkutsk

Valves slightly gomphonemoid-cuneate with almost straight margins. Head pole obtusely cuneiform with rounded vertex, foot pole narrower. Length 13-31 $\mu \mathrm{m}$, breadth 3.3-4.6 $\mu \mathrm{m}$. Raphe filiform and almost straight. No clear distinction between internal and external central raphe endings. Axial area narrow and parallel, central area transverse with 1-2 very much shortened striae at each side. The four striae limiting the central area end with one stigma each (not always clearly discernable in LM). Striae moderately or clearly radiate, 13-18 (in general 15-18) in 10 $\mu \mathrm{m}$, more densely arranged at the pole (about 20 in $10 \mu \mathrm{m}$ ) becoming sometimes almost parallel here. Striae pores indistinguishable in LM. $G$. marvanii is closely related to $G$. calcifugum 


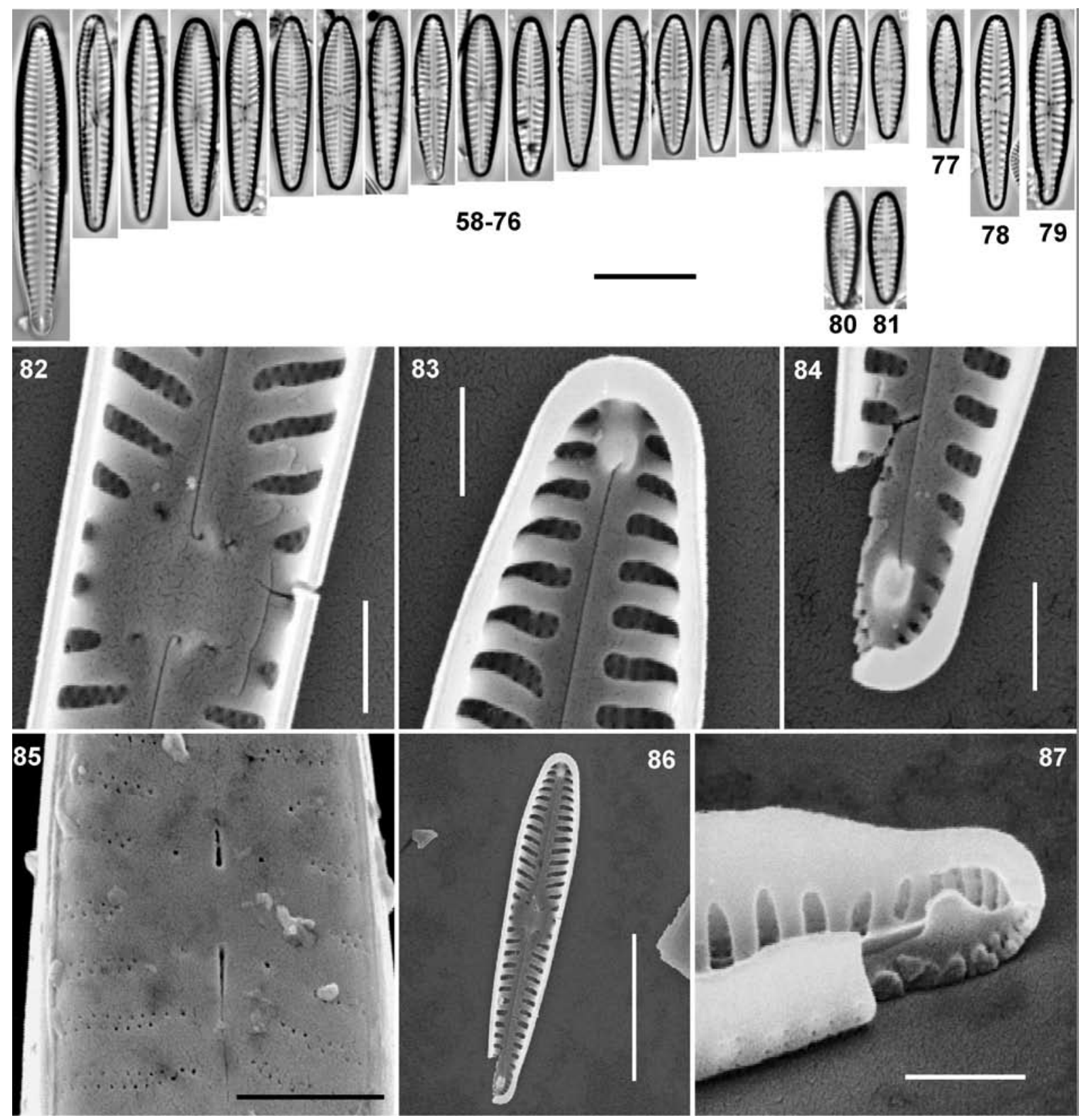

Figs 58-87. Gomphonema marvanii, Figs 58-81 LM: (58-76) Type material: (62) Holotypus; (77-78) Jenisej (S2783); (79) Jergacki (S2780); (80-81) Angara near Irkutsk (leg. 1987). Figs 82-87 SEM (type material): (82) Centre of valve interior, (83) Interior view of head pole, (84) Interior view of foot pole. No separated pore field but densely spaced alveoli, (85) Centre of valve exterior, (86) Interior view of whole valve, (87) Foot pole with transapical ribs in cross section. Scale bars $10 \mu \mathrm{m}$ (LM and Fig. 86.), $2 \mu \mathrm{m}$ (Figs 82-85, 87).

LANGE-Bert. et E. Reichardt (Syn. G. olivaceum var. minutissimum Hust.) and shows identical ultrastructures (Figs. 82-87): The striae are composed of double rows of small round foramina, internally simple alveolae without stubs or struts can be found. The alveoli and foramina run continuously into the basal pole where they are very densely arranged to form a pore field which in that kind is typical for the whole group (Figs 84, 87). Central raphe endings are straight and only very slightly expanded externally and shortly hooked to the same side internally. The stigmata show the well known irregular structures on the inside of the valve; they are more clearly separated from the striae on the primary side than on the secondary side, where they can be included in the alveoli in some cases (cf. REICHARDT 2009).

G. marvanii differs from G. calcifugum LANGEBERT. et E. REICHARDT mainly in the outline with a significantly higher length : breadth ratio which is 2.7-3.7 (about 3.1 on average) for G. calcifugum and about 4.0-6.3 (4.6 on average) in G. marvanii. Tuis (2005: 92) reports on narrower valves of $G$. 


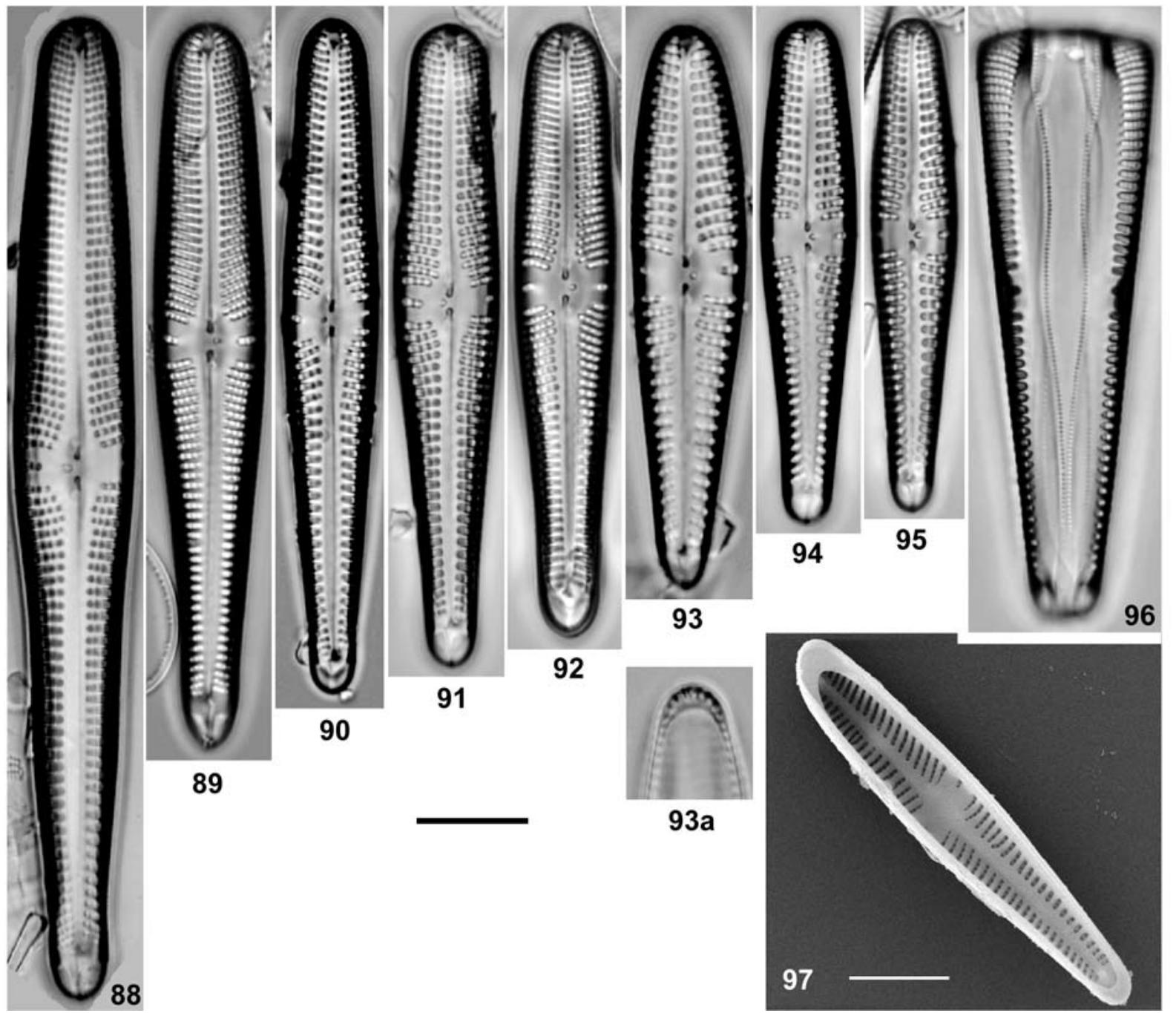

Figs. 88-97. Gomphonema liyanlingae. Figs. 88-96 LM: (88, 94, 95) Jergacki (S2779); (89, 90, 92, 96) Jenisej (S2783); (91, 93) Jergacki (S2780), (93a) Head pole of Fig. 93 at low focus to show pseudoseptum; (96) Girdle view; (97) SEM. Interior view of whole valve (S2783). Scale bars $10 \mu \mathrm{m}$.

calcifugum (including G. separatipunctatum KoBAYASI nom. inval.) in Japanese lakes but the depicted specimens (cf. TuIJ l.c. or KOBAYASI 1965: 30, figs. 8a, b) do not agree with G. marvanii.

The new species was found regularly but without strong appearance in different samples from River Angara in and near Irkutsk, rarely in Lake Baikal, in River Jenisej and in sample S2780 from a stream in the Jergacki Mountains, Western Sajan. Probably it is present in a sample from the reservoir at Bratsk, too.

\section{Gomphonema liyanlingae Metzeltin et LANGe- BERTALOT (Figs 88-103)}

This conspicuous diatom with coarsly punctate striae, characteristic arrangement of the striae in the centre of the valve and the distinct pseudoseptum at the head pole was found in samples from the
Jergacki region, in Jenisej River and in the River Angara in Irkutsk. During the preparation of this paper it was described by Metzeltin et LangeBert. (in Metzeltin, Lange-Bert. \& Nergui, 2009). Although these authors report the species from one locality only it seems to be widespread at least in Siberia, Mongolia and western China. A search in the literature resulted in the following figures which clearly show this species: SKVORTZOV 1937, pl. 14/25 (Lake Baikal) and SснміDт et al. (1874-1959) pl. 266/34 (China). Skvortzov (1937: 354) reports this diatom as ,,very common in Baikal". The occurrence in Lake Baikal is confirmed by the actual findings in the Angara river in Irkutsk. It is interesting to note that this or a similar diatom was not found by SKVORTZOV (1969) in the River Jenisej.

Observations in SEM show kidney-shaped 

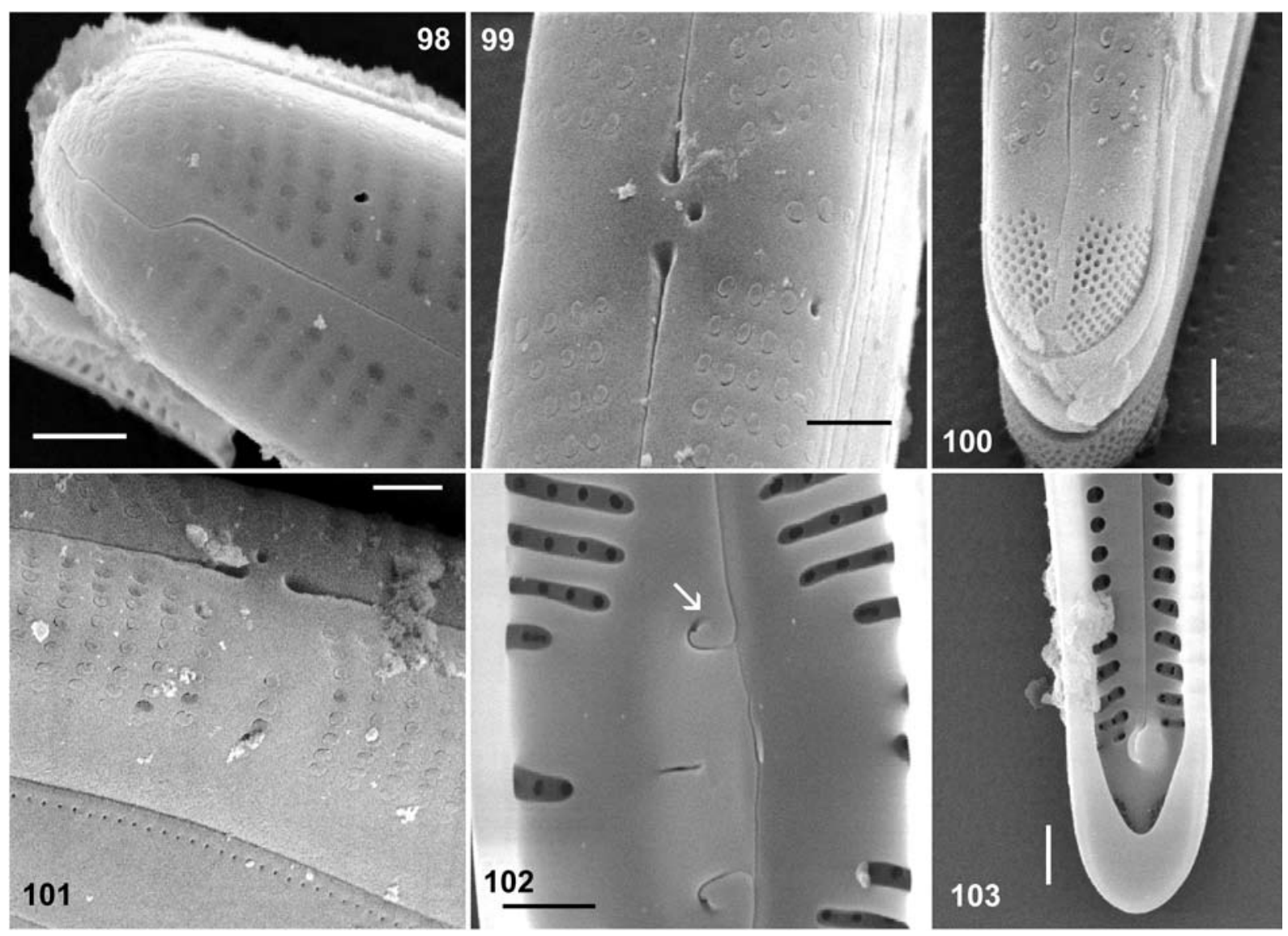

Figs 98-103. Gomphonema liyanlingae. SEM (S2783): (98) Exterior of head pole; (99) Centre of valve exterior; (100) Exterior of foot pole with pore field; (101) Centre of valve showing mantle exterior. Row of poroids in a girdle band, mantle without additional pores; (102) Inside view of valve centre. Note the shallow appendages at the endings of the recurved central fissures (arrow); (103) Interior of foot pole showing pseudoseptum and helictoglossa. Scale bars $2 \mu \mathrm{m}$.

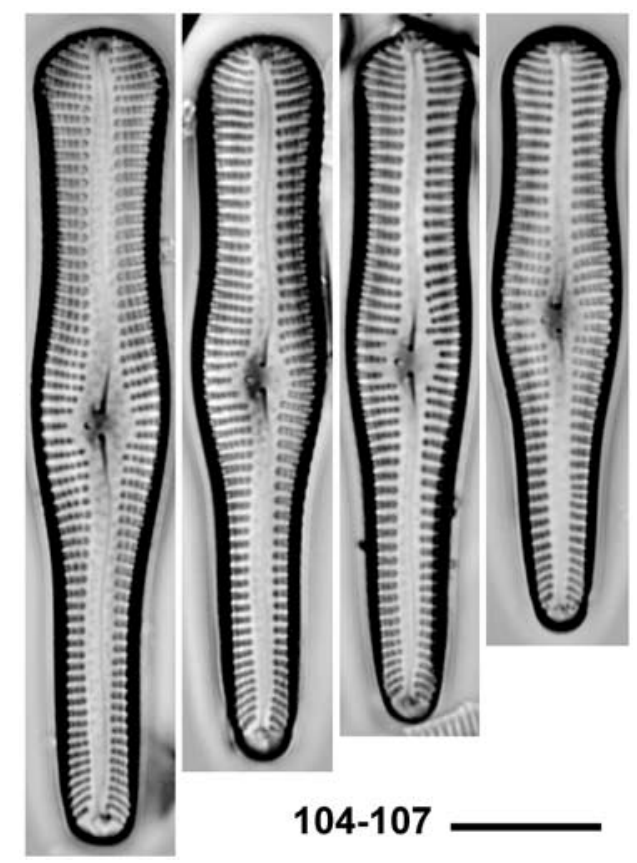

Figs 104-107. Gomphonema khentiiense. LM. Scale bar 10 $\mu \mathrm{m}$. foramina running continuously over the margin of the valve into the mantle which lacks additional structures (Fig. 101). External central raphe fissures nearly straight with conspicuous drop like endings. The round stigma opening can be seen right next to them (Fig. 99). Foot pole with well developed, separated and bisected pore field (Fig. 100). Looking at the inside of the valves the pseudosepta at both poles are striking (Figs. 97). Alveoli with straight margins, no stubs or struts are present. The recurved central raphe fissures end with pore-like structures, which bear shallow appendages. Internal stigma opening slit like (Fig. 102).

\section{Gomphonema khentiiense Metzeltin, Lange-B. et Nergui (Figs 104-107)}

This recently described Gomphonema (Metzeltin, Lange-Bert. \& Nergui, 2009) was found in streams in the Jergacki region (S2779, S2790) on silicate subsoils. The ecological data seem to be similar as given in Metzeltin, Lange-Bert. 
\& Nergui (2009). As in all species around $G$. capitatum EHRENB. the striae are composed of uniseriate areolae throughout, contrary to the $G$. truncatum EHRENB. group which shows biseriate areolae in the marginal parts of the valves (see REICHARDT 2001).

\section{Acknowledgements}

The author would like to thank Veronika Eckart for collecting, Prof. Dr. Dr. h.c. Horst Lange-Bertalot for materials from River Angara and Julma Ölkky, Ditmar Metzeltin for some slides and parts of the unpublished manuscript of Metzeltin, Lange-Bert. \& Nergui (2009) and Peter Lee Mancino for correcting parts of the English script.

\section{References}

Foged, N. (1993): Some diatoms from Siberia, especially from Lake Baikal. - Diatom Research 8: 231-279.

Kobayasi, H. (1965): Notes on the New Diatoms from River Arakawa. (Diatoms from River Arakawa 4.). - J. Jap. Bot. 40: 347-351, 2 pls.

LAnge-Bertalot, H. \& Metzeltin, D. (1996): Indicators of Oligotrophy; 800 taxa representative of three ecologically distinct lake types. - In: LANGE-Bertalot, H. (ed.): Iconographia Diatomologica:. Annotated diatom monographs. Vol. 2. Ecology-Diversity-Taxonomy. - 390 pp., Koeltz Scientific Books, Königstein.

Metzeltin, D., Lange-Bertalot, H. \& Nergui, S. (2009): Diatoms in Mongolia.- In: LAngEBertalot, H.(ed.): Iconographia Diatomologica. Annotated diatom micrographs. Vol. 20. - 686 pp., A.R.G. Gantner, Ruggell, Liechtenstein.

Popovskaya, G.I., Genkal S.I. \& Likhoshway Y.V. (2002): Diatoms of the plankton of Lake Baikal. Atlas and key. - In: MaKarova, V.I. \& Trifonova, I.S. (eds): Guides and keys to identification of fauna and flora of Lake Baikal. - 168 pp., Novosibirsk, "Nauka".

Reichardt, E. (1997): Taxonomische Revision des Artenkomplexes um Gomphonema pumilum (Bacillariophyceae). - Nova Hedwigia 65: 99129.

Reichardt, E. (1999): Zur Revision der Gattung Gomphonema. Die Arten um G. affine/insigne, $G$. angustatum/micropus, $G$. acuminatum sowie gomphonemoide Diatomeen aus dem Oberoligozän in Böhmen. - In: LANGE-BERTALOT, H. (ed.): Iconographia Diatomologica: Annotated diatom monographs. Vol. 8. Taxonomy. - 203 pp., A.R.G. Gantner, Ruggell, Liechtenstein.
ReICHARDT, E. (2001): Revision der Arten um Gomphonema truncatum und G. capitatum. In: JAHN, R., Kociolek, J.P., Witkowski, A. \& Compère, P. (eds): Lange-Bertalot-Festschrift. Studies on diatoms, dedicated to Prof. Dr. Dr. h.c. Horst Lange-Bertalot on the occasion of his $65^{\text {th }}$ birthday. - pp. 187-224., A.R.G. Gantner, Ruggell, Liechtenstein.

REICHARDT, E. (2009): Silikatauswüchse an den inneren Stigmenöffnungen bei Gomphonema-Arten. Diatom Research 24: 159-173.

SCHMIDT, A. et al. (1874-1959): Atlas der Diatomaceenkunde. - Heft 1-120, Tafeln 1-460. Aschersleben, Leipzig.

Skvortzov, B.V. (1937): Bottom diatoms from Olhon Gate of Baikal Lake, Siberia. - The Philippine Journal of Science 62: 293-377, 18 pls.

Skvortzov, B.V. (1969): Diatoms from Yenisei River and its Tribuarities, Middle Part of Siberia, Western Asia. - The Philippine Journal of Science 98: 57-113, 22 pls.

Tuj, A. (2005): Taxonomy of the Gomphoneis tetrastigmata species complex. - Bull. Natn. Sci. Mus., Tokyo, Ser. B, 31: 89-108.

(C) Czech Phycological Society

Received April 20, 2009

Accepted June 23, 2009 